\title{
EXOPOLYSACCHARIDES FROM YEAST: INSIGHT INTO OPTIMAL CONDITIONS FOR BIOSYNTHESIS, CHEMICAL COMPOSITION AND FUNCTIONAL PROPERTIES - REVIEW
}

\author{
Iwona Gientka ${ }^{\bowtie}$, Stanisław Błażejak, Lidia Stasiak-Różańska, \\ Anna Chlebowska-Śmigiel \\ Department of Biotechnology, Microbiology and Food Evaluation, Warsaw University of Life Sciences - SGGW \\ Nowoursynowska 159C, 02-776 Warsaw, Poland
}

\begin{abstract}
The yeast exopolysaccharides (EPS) are not a well-established group of metabolites. An industrial scale of this EPS production is limited mainly by low yield biosynthesis. Until now, enzymes and biosynthesis pathways, as well as the role of regulatory genes, have not been described. Some of yeast EPS show antitumor, immunostimulatory and antioxidant activity. Others, absorb heavy metals and can function as bioactive components of food. Also, the potential of yeast EPS as thickeners or stabilizers can be found. Optimal conditions for the biosynthesis of yeast exopolysaccharides require strong oxygenation and low temperature of the culture, due to the physiology of the producer strains. The medium should contain sucrose as a carbon source and ammonium sulfate as inorganic nitrogen source, wherein the $\mathrm{C}: \mathrm{N}$ ratio in the substrate should be 15:1. The cultures are long and the largest accumulation of polymers is observed after 4 or 5 days of culturing. The structure of yeast EPS is complex which affects the strain and culture condition. The EPS from yeast are linear mannans, pullulan, glucooligosaccharides, galactooligosaccharides and other heteropolysaccharides containing $\alpha-1,2 ; \alpha-1,3 ; \alpha-1,6 ; \beta-1,3 ; \beta-1,4$ bonds. Mannose and glucose have the largest participation of carbohydrates forming EPS.
\end{abstract}

Key words: yeast, exopolysaccharides, EPS

\section{INTRODUCTION}

According to IUPAC-IUB nomenclature, polysaccharides are polymers of monosaccharides joined by glycosidic bonds with a degree of polymerization higher than 10 (Badel et al., 2011). Extracellular polymers produced by microorganisms are referred to as EPS (extracellular polymeric substances), and when composed of sugars, they are referred to as exopolysaccharides. They are involved in the formation of biofilms and perform protective functions, e.g., against dehydration and osmotic stress (Breierová et al., 2005).
Also soil formation properties are attributed to them (Turkiewicz, 2006). The ability to secrete biopolymers is demonstrated by microorganisms belonging to different taxonomic groups. Due to composition, structure and physical properties, EPS found an application in food production. These include inter alia xanthan, dextran, gellan produced by bacteria, as well as pullulan or scleroglucan secreted by molds.

Extracellular polysaccharides are produced by many species of yeast, such as strains of Bullera, 
Candida, Cryptococcus, Debaryomyces, Lipomyces, Pichia, Pseudozyma Rhodotorula and Sporobolomyces genera. Production of EPS is related to the secondary metabolism of yeast, and their structure and physical properties depend on many factors, which include the composition of the culture medium and fermentation conditions such as $\mathrm{pH}$, temperature and oxygen concentration (Rusinova-Videva et al., 2010). Unfortunately, the low yield of these metabolites biosynthesis prevents their production on an industrial scale and limits their widespread use. Selection of highyielding strains, optimization of biosynthesis conditions, as well as recognition of molecular mechanisms and biochemical basis of overproduction are the tasks necessary for industrial exopolysaccharides application. This article provides an overview of the state of knowledge in the field of EPS biosynthesis by yeast.

\section{FUNCTIONAL PROPERTIES OF YEAST EPS AND POSSIBILITIES OF THEIR USE}

It has been known for a long time that yeast can be produced of galactooligosaccharides and glucooligosaccharides, which enhance the proliferation of bifidobacteria in the intestines. For example, Sporobolomyces singularis produces galactooligosaccharides (Gorin et al., 1964). R. minuta yeasts produce galactooligosaccharides in the culture with lactose, and glucooligosaccharides in media with cellobiose (Onishi and Yokozeki, 1996). Also, the strains of the Lipomyces, Pichia, Kluyveromyces, Debaryomyces, Candida, Torulopsis, Bullera and Brettanomyces genus produce galactooligosaccharides in media with lactose stimulating the growth of Bifidobacterium. In the general structure of these biopolymers Gal-(Gal) $)_{n}-\mathrm{Glc}, \mathrm{Gal}$ symbol is a molecule of galactose, Glc molecule of glucose, and $n$ is in the range of 1-4 (US Patent, 1994).

Mannan produced by R. glutinis AHU 3479 is used as an immunoreactive antigen in the serological diagnosis of leptospirosis. The disease is caused by bacteria of Leptospira genus, which antigens demonstrate a common skeletal structure. Mannan may cross-react with $\operatorname{IgG}$ and/or IgM antibodies specific to Leptospira (Matsuo et al., 2000).

The extracellular phosphomannan synthesized by Pichia holstii was used for the production of PI-88 medicament (Khachigian and Parish, 2004). In the view of clinical trials, this polysaccharide heparinase inhibitor exhibits an antitumor activity (Rusinova-Videva et al., 2011). Chemical structure of exopolysaccharide synthesized by $P$. holstii NRRL Y-2448 was investigated and described (Parolis et al., 1998). The side chains of the polymer, which were monophosphates, penta- and oligosaccharides of low molecular mass, were removed using mild acidic hydrolysis. The main chain accounted for only $10 \%$ of the whole polymer mass, which proves that the exopolysaccharide was very highly branched (Parolis et al., 1996).

Linear mannans produced by $R$. rubra (synonym R. mucilaginosa) showed antitumor activity in experimental animals, and their sulfate forms stimulated the development of antibodies and macrophages (Elinov et al., 1995). Furthermore, they showed a clear effect of cells protection against UV radiation (Ulyanova et al., 1992). Polymer produced by Rhodotorula glutinis, composed of mannose, glucose and arabinose (at a molar ratio of 3.2:1.0:0.8) demonstrated an antioxidant, antiviral and antitumor activity (Ghada et al., 2012).

Physical characteristics of yeast exopolymers, in particular their ability to form dense solutions in aquatic environment, caused the industry interest in these bioproducts. The potential of EPS is manifested in the possibility of their use as thickeners and stabilizers both in food and in cosmetics. Therefore, the physical parameters such as, for example, rheological traits of aqueous EPS solutions, stability in water-oil emulsions, and the ability to bind water, are essential for their application. Aqueous solutions of EPS from Rhodotorula yeasts showed the features of pseudoclassical non-Newtonian fluids (Cho et al., 2001). Glucomannan produced by $S$. salmonicolor $\mathrm{AL}_{1}$ increases the efficiency of emulsions formation and their stability in the tanning lotions (Kuncheva et al., 2007). A promising stabilizer of dispersion systems in cosmetics production is crylan, heteroglucan secreted by Cr. laurentii (Tikhomirova et al., 1998). The use of yeast EPS in combination with other polysaccharides, for example xanthan, increases the strength parameters and the viscosity value of these mixtures (Grigorova et al., 1999; Vlaev et al., 2013).

Yeast exopolysaccharides may be bioactive food components. The use of EPS produced by Cryptococcus laurentii yeast as a food additive which reduces 
the concentration of cholesterol and triglycerides in blood serum was patented in 2002 (Ananeva et al., 2002). Previously, the process of this exopolysaccharide production by microbiological biosynthesis was also patented (Ananeva and Vitovskaja, 2000).

According to Elinov et al. (1999), it is possible to use yeast exopolymers for heavy metals absorption. Lutelan (EPS produced by Cr. luteolus) is characterised by a high capacity for chemical elements binding, for example iron and copper ions.

It is worth to emphasize, that the recognition of the mechanisms of extracellular polysaccharides production by microorganisms is also important in medicine. EPS provide a heterogeneous three-dimensional form to biofilms, facilitate adhesion of pathogenic strains cells. As a result, they favor the formation of opportunistic infections of mycoses type. For example, one of the virulence factors of pathogenic Cryptococcus neoformans species is the capsule composed of glucuronoxylomannan, galactoxylomannan and mannoproteins (Buchanan and Murphy, 1998). Similarly, the presence of $\beta$ - $(1,3)$ bonds in polysaccharides secreted by $C$. albicans, which are not metabolized in human organism, causes the symptoms of infection (Szymankiewicz and Kowalewski, 2005). Food industry seeking the effective methods of preventing biofilms formation is interested in the mechanisms of extracellular polymers production.

\section{SOURCES OF ISOLATION OF EFFICIENT STRAINS PRODUCING EXOPOLYSACCHARIDES}

Yeast inhabiting the cold ecosystems have focused an interest, not only due to their metabolic adaptation to extreme environmental conditions, but also the possibility of valuable substances obtaining, like discussed herein exopolysaccharides, and enzymes, lipids or carotenoids (Rusinova-Videva et al., 2011; Turkiewicz, 2006).

The yeast strains isolated from penguin feathers and Arctic soil (Pavlova et al., 2004; 2009), as well as lichens and mosses (Pavlova et al., 2004; Rusinova-Videva et al., 2011), were examined towards the ability of extracellular polysaccharides production. The isolated psychrophilic strains, capable of large quantities of EPS production, belong to Sporobolomyces, Cryptococcus, Debaryomyces, Rhodotorula and Pseudozyma genera. The source of yeasts characterized by the potential for extracellular biopolymers production may also be soil (Ghada et al., 2012). A similar ability to produce extracellular polymers was demonstrated for some strains of yeast isolated from milk kefir (Gientka and Madejska, 2013).

\section{EFFECTS OF MEDIUM COMPONENTS ON EPS BIOSYNTHESIS}

The factors that affect amount of extracellular polysaccharides produced by the yeasts include the medium composition, in particular the source of carbon and nitrogen, $\mathrm{pH}$, as well as culture conditions: temperature, oxygenation, stirring, inoculum quantity and time of the culture.

Suitable medium for exopolysaccharides biosynthesis must contain assimilated sources of carbon and nitrogen. The sources of carbon are monosaccharides in the form of pentoses, hexoses, as well as disaccharides and trioses. Yeasts produce varying amounts of EPS in media containing, among others, glucose, sucrose, xylose, ribose, arabinose, galactose, mannose, rhamnose, raffinose, trehalose (Pavlova et al., 2004; Rusinova-Videva et al., 2011). Sucrose is considered the most optimum carbon source for EPS production for the majority of producer strains. In a medium containing sucrose at concentration of $4 \%$, Cryptococcus laurentii $\mathrm{AL}_{62}$, Sporobolomyces salmonicolor $\mathrm{AL}_{1}$ and Sporobolomyces salmicolor $\mathrm{AL}_{36}$ strains produce more than $5 \mathrm{~g} / 1$ EPS (Pavlova et al., 2004; 2009). Glucose, the fastest assimilable source of $\mathrm{C}$, in identical concentration reduces the amount of polymer secreted to a little more than $3 \mathrm{~g} / 1$. Similarly, the strains of Cryptococcus genus much more preferred sucrose than glucose, as evidenced by more than 3-fold higher efficiency of EPS biosynthesis. Among the waste carbon sources which may be a carbon substrate in the media for EPS synthesis, molasses were tested. Yeasts demonstrated a large biomass increase, however EPS synthesis, although sucrose dominates in this substrate, occurred at a very low level (Grigorova, 1999).

The possibility of EPS obtaining on other than carbohydrate carbon sources has not been tested so far. In turn, the ability of yeast to produce EPS in media containing sugars non-assimilated by them was demonstrated, provided however the use of mixed 
cultures. Lactose-negative yeasts Rhodotorula glutinis and homofermentative lactic acid bacteria Lactobacillus helveticus were co-cultured in a medium containing lactose (4.2\%). Under such conditions, R. glutinis produced EPS in amount of $9.2 \mathrm{~g} / 1$ (Frengova et al., 1997). Also mixed culture of Rhodotorula rubra and yoghurt bacteria of Streptococcus thermophilus and Lactobacillus bulgaricus genus resulted in production of large amounts of exopolysaccharides (Simova et al., 2005).

The source and concentration of nitrogen in the medium play an important role in polymers production efficiency. Peptone, yeast extract, as well as inorganic sources in the form of ammonium salts or nitrates were used as nitrogen source. The largest amounts of exopolysaccharides were obtained in media containing $0.2 \%$ to $0.25 \%$ of ammonium sulphate (Cho et al., 2001). The use of other ammonium salts, e.g., $\mathrm{NH}_{4} \mathrm{Cl}$ or $\mathrm{NH}_{4} \mathrm{NO}_{3}$, resulted in a greater increase of biomass, but the reduction in polymers biosynthesis efficiency was observed at the same time (Grigorova et al., 1999). The factor determining the efficiency of EPS biosynthesis, except carbon and nitrogen source, is their molar ratio. It was found in the study conducted by Cho et al. (2001) that Rhodotorula glutinis yeasts were able to produce the highest amount of polymers when $\mathrm{C}: \mathrm{N}$ ratio was 15:1. Higher $\mathrm{C}: \mathrm{N}$ ratio in the medium caused an activation of the mechanism of other reserve substances accumulation, including fats. Concurrently, too low $\mathrm{C}: \mathrm{N}$ ratio was unsuitable for exopolysaccharides synthesis, since almost all carbon is consumed for biomass production. Synthesis of extracellular polymers begins at exhaustion of nitrogen source and an excess of carbon, which coincides with the end of logarithmic phase. EPS content in the medium reaches its maximum between 96 and 120 hour, which depends on the strain and culture conditions.

\section{EFFECT OF ENVIRONMENTAL FACTORS ON EPS SYNTHESIS}

The inoculum culture of EPS forming strains is carried out in conditions ensuring optimal growth of biomass for 42-48 hours (Cho et al., 2001; Pavlova et al., 2009; Poli et al., 2010), usually in YPD medium. The size of inoculum introduced to the production medium applied in the cited publications was from $1 \%$ to $10 \%$ $\mathrm{v} / \mathrm{v}$. For example, the synthesis of EPS by R. glutinis strain proceeded with the highest efficiency when inoculum was $7.5 \%$, and the inoculum culture was carried out at $22^{\circ} \mathrm{C}$ with stirring at $180 \mathrm{rpm}$ (Ghada et al., 2012). Inoculum in a similar range $(8 \%$ to $10 \%)$ was beneficial in the case of EPS synthesis by yeasts from Antarctic ecosystems (Rusinova-Videva et al., 2010). In turn, in case of Sp. salmonicolor and Rhodotorula acheniorum culturing in bioreactors, inoculum in a volume of $1 \%$ guaranteed efficient EPS biosynthesis (Pavlova et al., 2004; 2005).

Temperature of the culture is chosen according to the requirements of the strains, especially that most of the producer strains is psychrophilic. In order to obtain EPS, Cryptococcus laurentii $\mathrm{AL}_{62}$ strain was cultured at $22^{\circ} \mathrm{C}$. Sporobolomyces salmonicolor $\mathrm{AL}_{1}$ (Pavlova et al., 2004) and Rhodotorula glutinis (Cho et al., 2001) were cultured at the same temperature. Cryptococcus flavus $\mathrm{A}_{51}$ was incubated at $24^{\circ} \mathrm{C}$ (Pavlova et al., 2009), while Rhodotorula acheniorum MC under conditions of the bioreactor at a temperature of $26^{\circ} \mathrm{C}$ (Pavlova et al., 2005). In the case of the latter strain, the largest biomass yield was obtained at a lower temperature of $20^{\circ} \mathrm{C}$. It may be thus concluded that the optimum temperature for EPS biosynthesis does not necessarily coincide with the optimum growth temperature.

The cultures focused on EPS biosynthesis require high oxygenation of the culture. Under the conditions carried out in flasks in the shaker, it allowed to obtain a high ratio of the total flask volume to the culture volume (e.g. flasks of a volume of $500 \mathrm{ml}$ were only filled with $50 \mathrm{ml}$ of medium) (Pavlova et al., 2004). The cultures carried out on a larger scale using a bioreactor require optimization of the stirring and oxygenation parameters. Stirrer rotation speed optimum for Rhodotorula acheniorum MC strain was $500 \mathrm{rpm}$ and aeration was $0.75 \mathrm{vvm}$. Under these conditions, $6.2 \mathrm{~g}$ $\mathrm{EPS} / 1$ was obtained. At the same oxygenation level but lower stirring (300 rpm), the amount of EPS was only $2 \mathrm{~g} / \mathrm{l}$, while in the case of $800 \mathrm{rpm}$ it was nearly $4 \mathrm{~g} / \mathrm{l}$. The highest yield of EPS synthesis by S. salmonicolor under bioreactor conditions was obtained during stirring at $400 \mathrm{rpm}$ and aeration of $1 \mathrm{vvm}$. Increasing speed of the stirrer resulted in a reduction of produced EPS amount (Vlaev et al., 2013). 
The phenomenon of strong and rapid acidification of the medium is observed during the accumulation of extracellular polymers. The initial $\mathrm{pH}$ of media established at about 5.3-5.6, already on the first day can decrease to the value of about $2.30-1.65$ depending on the producer. A strong acidification of the medium is maintained until the end of the culture. Such a phenomenon was observed in a number of studies on the synthesis of exopolysaccharides by the yeasts. The change in $\mathrm{pH}$ to a value within the range of 1.65-2.13 was reported during the synthesis of EPS by strains of Cryptococcus genus (Pavlova et al., 2004), while in the case of Pseudozyma antarctica $\mathrm{A}_{104}$ to 1.75 . Also several strains of $R$. minuta and Sp. salmonicolor yeasts acidified the culture environment to a value of about 2.0 (Poli et al., 2010). It should be emphasized that the strength of acidification depends on nitrogen source, and is higher in case of inorganic salts application.

The mechanism of rapid use of ammonium ion resulting in protons ejection from the yeast cells and medium acidification is considered to be the reason for the strong $\mathrm{pH}$ lowering during EPS biosynthesis in mineral medium (Cho et al., 2001). It should be emphasized, that low $\mathrm{pH}$ is a necessary precondition for EPS biosynthesis. During Rh. acheniorum MC culturing with continuous neutralization of the optimized medium with $\mathrm{CaCO}_{3}$, the yield of EPS synthesis was very low (Grigorova et al., 1999). Moreover, the composition of obtained EPS differed significantly from that obtained in the culture without neutralization. Among the carbohydrates included in the polymer obtained in the environment with adjusted $\mathrm{pH}$, glucose was $44.5 \%$, while mannose $27 \%$. In turn, exopolymer obtained in the medium without $\mathrm{pH}$ adjustment was characterized by high, more than $64 \%$, mannose content. Similar relationships were observed when culturing $R$. glutinis KCTC strain (Cho et al., 2001), where the $\mathrm{pH}$ was maintained on a constant level.

Organic nitrogen in the form of peptone or yeast extract adversely affects the synthesis of EPS. At the same time, it was observed that the $\mathrm{pH}$ of such media was not subjected to a rapid decrease. For the yeast of the Candida genus, acidity increased by 0.2 units (Gientka and Madejska, 2013), and for R. acheniorum $\mathrm{MC}$ it decreased by about 1.5 units (Grigorova et al., 1999).
An important feature of the discussed cultures culturing is an increase in medium density and viscosity. For example, after $120 \mathrm{~h}$ of $S$. salmonicolor culturing in medium containing $5 \%$ sucrose, maximum viscosity reached the value of $15.4 \mathrm{MPa} \cdot \mathrm{s}$ (Pavlova et al., 2004). In the culture of $R$. acheniorum MC, the highest EPS content was found in the fifth day, and the highest viscosity values (max. 10.14 MPa's) $24 \mathrm{~h}$ earlier (Grigorova et al., 1999). The authors explain the reduction in viscosity during culturing by probable depolymerization of EPS macromolecules. It should be noted that the dynamic viscosity depends, like the content of EPS, on many factors and in particular on carbon and nitrogen sources and their concentrations.

\section{CHEMICAL COMPOSITION OF YEAST EPS}

Isolation and purification of yeast polymers is based on their physical properties and ability to dissolve in water, and absence of these in organic solvents. Precipitation of the so-called raw EPS from post-culturing fluid, from which biomass was previously removed by centrifugation, involves an application of ethanol, isopropanol, and methanol. The latter, due to its toxicity, is not recommended for biopolymers separation for the production of food or medicaments.

Except carbohydrates, crude (unpurified) preparation may contain proteins and mineral salts. For example, crude EPS originating from Sporobolomyces salmonicolor $\mathrm{AL}_{1}$ culture contains $5.3 \%$ proteins and $4.5 \%$ mineral salts, respectively (Pavlova et al., 2004). EPS produced by C. laurentii $\mathrm{AL}_{62}$ contained over $12 \%$ of proteins, and nearly $4 \%$ of mineral salts. The carbohydrates content in the composition of the raw EPS product is significantly affected by nitrogen source. EPS obtained after $R$. acheniorum MC culturing in medium containing $\left(\mathrm{NH}_{4}\right)_{2} \mathrm{SO}_{4}$ was composed of more than $76 \%$ of carbohydrates, while obtained in medium with $\mathrm{NH}_{4} \mathrm{Cl}$ contained lower amounts of carbohydrates and considerably more protein and ash (Grigorova et al., 1999).

The composition of the examined so far yeast exopolysaccharides is presented in Table 1. The total share of carbohydrates in the crude extracellular polymers depending on the strain of yeast and cultivation conditions ranges from $59 \%$ to over $92 \%$. The sugars forming polysaccharides structure include glucose, 
Gientka, I., Błażejak, S., Stasiak-Różańska, L., Chlebowska-Śmigiel, A. (2015). Exopolysaccharides from yeast: insight into optimal conditions for biosynthesis, chemical composition and functional properties - review. Acta Sci. Pol. Technol. Aliment., 14(4), 283-292. DOI: 10.17306/J.AFS.2015.4.29

Table 1. Characteristics of exopolymers produced by efficient yeast strains

\begin{tabular}{|c|c|c|c|}
\hline Species & Crude EPS & Purified EPS/Molecular weight & Author \\
\hline C. laurentii $\mathrm{AL}_{62}$ & $\begin{array}{l}\text { Carbohydrates } 83.7 \% \text {, including: } \\
\text { - mannose } 33.6 \% \\
\text { - xylose } 45.2 \% \\
\text { - glucose } 18.4 \% \\
\text { - other } 2.7 \%\end{array}$ & $\begin{array}{l}\text { A few fractions: } \\
1.24 \mathrm{e}+06 \mathrm{Da}-210 \mathrm{Da} \\
(60 \% 8000 \mathrm{Da})\end{array}$ & $\begin{array}{l}\text { Rusinova-Videra et al. } \\
\text { (2011) }\end{array}$ \\
\hline C. laurentii CCY 17-3-16 & $\begin{array}{l}\text { Carbohydrates } 59.3 \% \text {, including: } \\
\text { - mannose } 60.2 \% \\
\text { - xylose } 20.6 \% \\
\text { - galactose } 9.9 \% \\
\text { - glucose } 7.8 \% \\
\text { - } \text { arabinose } 1.6 \%\end{array}$ & $\begin{array}{l}\text { Three fractions: } \\
\text { I. } 1000 \mathrm{kDa} \\
\text { II. } 400-60 \mathrm{kDa} \\
\text { III. } 60-25 \mathrm{kDa}\end{array}$ & Breierová et al. (2005) \\
\hline C. utilis invertase(-) & \multicolumn{2}{|c|}{$\begin{array}{l}\text { Carbohydrates } 98.7 \% \text {, including glucose: mannose } \\
\text { (in molar ratio of } 5.1: 1 \text { ) }\end{array}$} & Chiura et al. (1982b) \\
\hline Cr. flavus $\mathrm{AL}_{51}$ & $\begin{array}{l}\text { Carbohydrates } 92.5 \% \text {, including: } \\
\text { - mannose } 55.1 \% \\
\text { - glucose } 26.1 \% \\
\text { - xylose } 9.6 \% \\
\text { - galactose } 1.9 \%\end{array}$ & $\begin{array}{l}\text { Homogenous } \\
1.01 \mathrm{MDa}\end{array}$ & Pavlova et al. (2009) \\
\hline R. glutinis & \multicolumn{2}{|c|}{$\begin{array}{l}\text { Carbohydrates, including: mannose, glucose and arabinose } \\
\text { (in molar ratio of } 3.2: 1.0: 0.8 \text { ) }\end{array}$} & Ghada et al. (2012) \\
\hline R. glutinis КСТC 7989 & $\begin{array}{l}\text { Carbohydrates } 85 \% \text {, including: } \\
\text { - mannose } \\
\text { - fucose } \\
\text { - glucose } \\
\text { - galactose } \\
\text { (in molar ratio of } 6.7: 0.2: 0.1: 0.1 \text { ) } \\
\text { uronic acid } 15 \%\end{array}$ & $1.0-3.8 \times 10^{5} \mathrm{Da}$ & Cho et al. (2001) \\
\hline R. acheniorum MC & $\begin{array}{l}\text { Carbohydrates } 85.6 \% \text {, including: } \\
\text { - mannose } 87.7 \% \\
\text { - glucose } 7.7 \% \\
\text { - galactose } 3.2 \% \\
\text { - fructose } 1.3 \%\end{array}$ & $\begin{array}{l}\text { Carbohydrates } 98.2 \% \text {, including: } \\
\text { - mannose } 92.8 \% \\
\text { - glucose } 7.2 \%\end{array}$ & $\begin{array}{l}\text { Grigorova et al. } \\
\text { (1999) }\end{array}$ \\
\hline R. acheniorum $\mathrm{MC}$ & $\begin{array}{l}\text { - } \text { mannose } 69.13 \% \\
\text { - glucose } \\
\text { - galactose } \\
\text { - fucose } \\
\text { - } \text { arabinose }\end{array}$ & $\begin{array}{l}\text { Two fractions: } \\
\text { I. } 310 \mathrm{kDa} \\
\quad \text { - mannose } 92.8 \% \\
\quad \text { glucose } 7.2 \% \\
\text { II. } 249 \mathrm{kDa} \\
\quad \text { - mannose } 90.6 \% \\
\text { - glucose } 9.4 \%\end{array}$ & Pavlova et al. (2005) \\
\hline Sp. salmonicolor $\mathrm{AL}_{1}$ & $\begin{array}{l}\text { Carbohydrates } 90.2 \% \text {, including: } \\
\text { - mannose } 42.6 \% \\
\text { - glucose } 54.1 \% \\
\text { - fucose } 3.3 \%\end{array}$ & $\begin{array}{l}\text { Carbohydrates } 98.9 \% \text {, including: } \\
\text { - mannose } 98.6 \% \\
\text { - glucose } 1.4 \%\end{array}$ & Pavlova et al. (2004) \\
\hline
\end{tabular}


mannose, galactose, fucose, arabinose, xylose, with the largest percentage represented by mannose, and glucose. Thus, most of the yeast exopolysaccharides are mannans or a glucomannans. EPS containing more than $50 \%$ of the mannose are classified as having biological activity.

Purification of crude EPS involves mannan precipitation with copper salts (e.g. Fehling reagents). Obtained thus water-insoluble complex is rinsed with $2 \%$ $\mathrm{KOH}$, then with ethanol and dissolved in distilled water. Then, the copper ions are separated using ion-exchange (e.g. Wofatit KSP). Polysaccharides are again precipitated with ethanol and dried under vacuum at $50^{\circ} \mathrm{C}$ (Grigorova et al., 1999). This process allows to remove mineral salts and proteins, and consequently to increase the percentage share of carbohydrates in the preparation (from about $76 \%$ to over $98 \%$ for $R$. acheniorum). Purification of the crude EPS also changes the composition of monosaccharides present in it. The polymer produced by $S$. salmonicolor was purified from fucose and glucose (from the content of $54 \%$ to $1.4 \%$ ), so that mannose content in the purified preparation exceeded 98\% (Pavlova et al., 2004). Purification reduced fructose and galactose content in EPS preparations from Rhodotorula (Grigorova et al., 1999).

Some yeasts produce different fractions of exopolymers during the same culture. Two fractions were obtained as a result of precipitation of EPS produced by Rhodotorula acheniorum MC. Fraction I was characterized by a compact, fibrous structure, and its molecular weight was $310 \mathrm{kDa}$, while fraction II was separated in the form of soft and loose mass $(249 \mathrm{kDa})$. Carbohydrates content in the purified fractions was $98.2 \%$ for fraction I, and $87.3 \%$ for fraction II (Pavlova et al., 2005). The yeasts that produce heterogeneous polymers in the same culture also include Candida laurentii CCY 17-3-16 (Breierová et al., 2005) and Candida laurentii $\mathrm{AL}_{62}$ (Rusinova-Videva et al., 2011).

The structure of the polymer can be one monomer. An example of the strain producing EPS composed entirely of D-mannose molecules is Pichia holstii NRRL Y-2448 (Parolis et al., 1996, 1998). The side chains with terminal mannose molecule, in which phosphate group is situated at the sixth carbon atom, are attached to the main chain with $\alpha-1,2$ or $\alpha$-1,4-glycosidic bonds. The content of phosphorus in the extracellular mannan largely depends on phosphates content in the medium, and when they are present in the medium, the synthesized exopolysaccharide contains the side chains (linked with $\alpha-1,6$-glycosidic bonds) of mannose linked with $\alpha-1,2$ and $\alpha-1,3$-glycosidic bonds. The polysaccharide forms a branched structures resembling starch or glycogen. Reduction of phosphates content in the culture medium leads to the production of mannan forms by the yeast, which contain lower number, but longer side chains. $R$. rubra yeasts produce linear mannans containing $\beta-1,3$ and $\beta-1,4$-glycosidic bonds (Pavlov et al., 1992). In turn, another species, Rhodotorula bacarum, is capable of pullulan biosynthesis (Chiura et al., 1982b).

It was noted, that except the enzyme, also extracellular glucomannan was formed $\left(1.56 \mathrm{~g} / \mathrm{dm}^{3}\right)$ in the course of the culture directed towards invertase production by Candida utilis ATCC 42402 strain (Chiura et al., 1982a). Extracellular glucomannan was isolated during the culturing of another Candida utilis strain, for which no invertase production was found. The crude preparation contained small amounts of protein (above 15) and $98 \%$ of carbohydrates, which consisted of glucose and mannose in a molar ratio of 5.7:1. The ratio of glucose and mannose was clearly different from that present in glucomannan produced by strains producing invertase (mannose-glucose 10:1). Moreover, in both cases, the produced polysaccharides differed from glucomannan present in the cell wall of Candida utilis, in which the ratio of glucose to mannose is 23:2 (Chiura et al., 1982b).

Two strains belonging to Sporobolomyces genus (NRRL Y-6493 and NRRL Y-6502) produce extracellular phosphorylated galactans during the culture in a medium containing glucose as the carbon source. D-galactose and D-galactose-6-phosphate were isolated from them after acidic hydrolysis, while $\alpha$-Dgalactose-1-phosphate after alkaline hydrolysis. Oxidation of polymers with periodate demonstrated that they have $\alpha-1,3$ and $\alpha-1,6$-glycosidic bonds (Slodki, 1996). Except sugars, the polymers may contain the particles of saccharic acids. For example, the presence of uronic acid, constituting more than $15 \%$ of carbohydrates in EPS originating from $R$. glutinis, was noted. Its presence gave a negative charge to the polymer (Cho et al., 2001). The example of acidic polymer isolated from post-culture fluids of $C$. laurentii was glucuronoxylomannan (Bartek et al., 2001). 
It was noted that the structure and chemical composition of the resulting polymers is subject to changes in stress conditions. The media containing peptone and yeast extract stimulated the synthesis of high molecular heteroglucan containing mannose, glucose and glucuronic acid. The crude EPS preparation produced by $C$. laurentii under conditions of salt stress, i.e. in media containing $10 \% \mathrm{NaCl}$, contained significantly less (only 13.8\%) of protein and less mannose (44\%) relative to the EPS obtained under identical conditions in a medium without salt (more than 33\% protein, and 60\% mannose) (Elinov et al., 1995). Generally, during stress the yeasts produce EPS of higher molecular weight and higher homogeneity (only two fractions, whereas normally three) (Breierová et al., 2005).

\section{SUMMARY}

Yeast exopolysaccharides, unlike bacterial ones, are not the well-recognised group of metabolites. Their production on an industrial scale is limited mainly by low yield of biosynthesis. For this reason, it has not been possible so far to describe their biosynthesis pathways, enzymes taking part in them and the role of regulatory genes. The efforts in the search for functional polysaccharides observed for several years, prove that yeast, despite previously poor productivity, are their attractive source. These are microorganisms considered as safe, they can rarely cause opportunistic infections and do not raise concerns of the consumers. They have documented industrial usefulness, physiology, biochemical and genetic processes. Yeast exopolysaccharides have many features that can be used in different ways. Some of them show antitumor, immunostimulatory and antioxidant activity. The other ones well absorb heavy metals, and some have already been patented as bioactive food components. Furthermore, the potential of yeast EPS as thickeners or stabilizers can be observed.

The structure and construction of yeast exopolymers is complex. They include linear mannans, branched heteropolysaccharides, galacto-and glucooligosaccharides, pullulan. Particular sugars may be connected with $\alpha-1,2 ; \alpha-1,3 ; \alpha-1,6 ; \beta-1,3 ; \beta-1,4$ glycosidic bonds. The largest percentage share among carbohydrates forming yeast EPS is demonstrated for mannose and glucose. Phosphate groups or other, e.g., uronic acid, are also found in the polymer particles. The chemical composition is affected by culture conditions, particularly carbon and nitrogen sources, as well as stress factors.

Optimum conditions for yeast exopolysaccharides biosynthesis require strong oxygenation and low temperature of the culture, due to the physiology of the producer strains. The medium should include sucrose and inorganic nitrogen source-preferably in the form of ammonium sulfate, wherein the $\mathrm{C}: \mathrm{N}$ ratio in the medium should be 15:1. The cultures are long and the largest accumulation of the polymers is observed on the 4th or 5th day, which is correlated with corresponding increase in the viscosity and density of the medium.

\section{REFERENCES}

Ananeva, E. P., Vitovskaja, G. A. (2000). Russian patent no. 2148648.

Ananeva, E. P., Vitovskaja, G. A., Burakova, M. A., et al. (2002). Russian patent no. 2177695.

Badel, S., Laroche, C., Gardarin, C., Petit, E., Bernardi, T., Michaud, P. (2011). A new method to screen polysaccharide cleavage enzymes. Enz. Microb. Technol., 48, 248-252.

Bartek, P., Kolarova, N., Capek, P. (2001). Isolation characterization of glycoproteins from the yeast Cryptococcus laurentii var. laurentii. II. Extracellular glycoproteins. Chem. Papers, 55, 261-268.

Basche, M., Gustafson, D. L., Holden, S. N., O’Bryant, C. L., Gore, L., ..., Eckhardt, S. G. (2006). A phase I: Biological and pharmacological study of the heparanase inhibitor PI-88 in patients with advanced solid tumors. Clin. Cancer. Res., 12, 5471-5480.

Breierová, E., Hromádková, Z., Stratilová, E., Sasinková, V., Ebringgerová, A. (2005). Effect of salt stress on the production and properties of extracellular polysaccharides produced by Cryptococcus laurentii. Z. Naturforsch., 60c, 444-450.

Buchanan, K. L., Murphy, J. W. (1998). What makes Cryptococcus neoformans a pathogen? Emerg. Inf. Dis., 4(1), 71-83.

Chi, Z., Zhao, S. (2003). Optimization of medium and cultivation conditions for pullulan production by a new pullulan-producing yeast strain. Enz. Microb. Tech., 33, 206-2011. 
Chiura, H., Iizuka, M., Yamamoto, T. (1982a). A glucomannan as an extracellular product of Candida utilis I. Production and characterization of a glucomannan. Agric. Biol. Chem. 46(7), 1723-1731.

Chiura, H., Iizuka, M., Yamamoto, T. (1982b). A glucomannan as an extracellular product of Candida utilis II. Structure of a glucomannan: characterization of oligosaccharides obtained by partial hydrolysis. Agric. Biol. Chem., 46(7), 1733-1742.

Cho, D. H., Chae, H. J., Kim, E. Y. (2001). Synthesis and characterization of a novel extracellular polysaccharide by Rhodotorula glutinis. Appl. Biochem. Biotechnol., 95(3), 183-193.

Elinov, N. P., Ananeva, E. P., Yaskovich, G. A. (1999). Activity of exoglycans as sorbents of ions of heavy metals. Appl. Biochem. Microbiol., 35, 168-171.

Elinov, N. P., Gurina, S. V., Ananeva, E. P. (1995). Immunobiological activity of yeast glicanes in the experiment. Mikol. Fytopat., 29, 39-43.

Frengova, G., Simova, E., Beshkova, D. (1997). Carotenoprotein and exopolysaccharide production by cocultures of Rhodotorula glutinis and Lactobacillus helveticus. J. Ind. Microbiol. Biotechnol., 18(4), 272-277.

Ghada, S. I., Manal, G. M., Moshen, M. S. A., Eman, A. G. (2012). Production and biological evaluation of exopolysaccharide from isolated Rhodotorula glutinins. Aust. J. Basic. Appl. Sci., 6(3), 401-408.

Gientka, I., Madejska, A. (2013). Evaluation of the usefulness of yeast strains isolated from kefirs in extracellular polymers synthesis. Adv. Agric. Sci. Prob. Iss., 574, 19-27 [in Polish].

Gorin, P. A. J., Spencer, J. T. F., Phaff, H. J. (1964). The structures of galactosyl-lactose and galactobiosyl-lactose produced from lactose by Sporobolomyces singularis. Can. J. Chem., 42(6), 1341-1344.

Grigorova, D., Pavlova, K., Panchev, I. (1999). Preparation and preliminary characterization of exopolysaccharides by yeast Rhodotorula acheniorum MC. Appl. Biochem. Biotechnol., 81(3), 181-191.

Khachigian, L. M., Parish, C. R. (2004). Phosphomannopentaose sulfate (PI-88): Heparan sulfate mimetic with clinical potential in multiple vascular pathologies. Cardiovasc. Drug. Rev., 22(1), 1-6.

Kuncheva, M., Pavlova, K., Panchev, I., Dobreva, S. (2007). Emulsifying power of mannan and glucomannan produced by yeasts. Int. J. Cosmet. Sci., 29(5), 377-384.

Matsuo, K., Isogai, E., Araki, Y. (2000). Utilization of exocellular mannan from Rhodotorula glutinis as an immunoreactive antigen in diagnosis of leptospirosis. J. Clin. Microbiol., 38(10), 3750-3754.
Onishi, N., Yokozeki, K. (1996). Glucooligosaccharide and galactooligosaccharide production by Rhodotorula minuta IFO879. J. Ferment. Bioeng., 82, 124-127.

Parolis, L. A. S., Duus, J., Parolis, H., Kenneb, L., Meldal, M., Bock, K. (1996). The extracellular polysaccharide of Pichia (Hansenula) holstii NRRL Y-2448: the structure of the phosphomannan backbone. Carbohydr. Res., 293(1), 101-117.

Parolis, L. A. S., Parolis, H., Kenneb, L., Meldal, M., Bock, K. (1998). The extracellular polysaccharide of Pichia (Hansenula) holstii NRRL Y-2448: The phosphorylated side chains. Carbohydr. Res., 309(1), 77-87.

Pavlov, G. M., Komeeva, A. E. V., Michailova, N. A., Ananyeva, E. P. (1992). Hydrodynamic properties of the fractions of mannan formed by Rhodotorula rubra yeast. Carbohydr. Polym., 19, 243-248.

Pavlova, K., Koleva, L., Krachanova, M., Panchev, I. (2004). Production and characterization of an exopolysaccharide by yeast. World J. Microbiol. Biotechnol., 20(4), 435-439.

Pavlova, K., Panchev, I., Hristozova, T. S. (2005). Physicochemical characterization of exomannan from Rhodotorula acheniorum MC. World J. Microbiol. Biotechnol., 21(3), 279-283.

Pavlova, K., Panchev, I., Krachanova, M., Gocheva, M. (2009). Production of an exopolysaccharide by antarctic yeast. Folia Microbiol., 54(4), 343-548.

Poli, A., Anzelmo, G., Tommonaro, G., Pavlova, K., Casaburi, A., Nicolaus, B. (2010). Production and chemical characterization of an exopolysaccharide synthesized by psychrophilic yeast strain Sporobolomyces salmonicolor $\mathrm{AL}_{1}$ isolated from Livingston Island, Antarctica. Folia Microbiol., 55(6), 576-581.

Rusinova-Videva, S., Pavlova, K., Panchev, I., Georgieva, K., Kuncheva, M. (2010). Effect of different factors on biosynthesis of exopolysaccharide from Antarctic yeast. Biotechnol. Biotechnol. Equip., 24, 507-511.

Rusinova-Videva, S., Pavlova, K., Georgieva, K. (2011). Effect of different carbon sources on biosynthesis of exopolysaccharide from Antarctic strain Cryptococcus laurentii $\mathrm{AL}_{62}$. Biotechnol. Biotechnol. Equip., 25(4), 80-84.

Rusinova-Videva, S., Pavlova, K., Metcheva, R. (2009). Studies of Antarctic yeast isolates for exopolysaccharide synthesis. Biotechnol. Biotechnol. Equip., 23(2), 888-891.

Simova, E. D., Frengova, G. I., Beshkova, D. M. (2004). Exopolysaccharides produced by mixed culture of yeast Rhodotorula rubra GED10 and yogurt bacteria 
(Streptococcus thermophilus 13a + Lactobacillus bulgaricus 2-11). J. Appl. Microbiol., 97(3), 512-519.

Slodki, M. E. (1996). The structure of extracellular phosphorylated galactans from Sporobolomyces yeast. J. Biol. Chem., 241(11), 2700-2706.

Szymankiewicz, M., Kowalewski, J. (2005). Evaluation of mucus formation ability by Candida albicans fungi depending on the site of strains isolation. Mikol. Lek., 12(4), 249-252.

Tikhomirova, O. M., Vitovskaya, G. A., Sinitskaya, I. A. (1998). Cellular polysaccharides of Cryptococcus laurentii (Kufferath) skinner, a producer of extracellular heteroglycan. Mikrobiologija, 67(1), 61-65.

Turkiewicz, M. (2006). Psychrophilic microorganisms and their biotechnological potential. KOSMOS Prob. Nauk Biol., 55(4), 307-320 [in Polish].
Ulyanova, L. P., Ananeva, E. P., Kashkina, M. A., Elinov, N. P., Budagov, R. S. (1992). Mikol. Fytopat., 26, 42-44.

US Patent: US 5294546 A. (1994). Method for production of a growth factor for Bifidobacterium sp.

Vlaev, S., Rusinova-Videva, S., Pavlova, K., Kuncheva, M., Panchev, I., Dobreva, S. (2013). Submerged culture process for biomass and exopolysaccharide production by Antarctic yeast: some engineering considerations. Appl. Microbiol. Biotechnol., 97(12), 5303-5313.

Wojtukiewicz, M. Z., Sierko, E., Szambora, P. (2009). Antiangiogenic treatment in patients with ovarian cancer. Onc. Clin. Pract., 5(A), 39-43.

Zhu, H., Sun, S. J. (2009). Effect of constant glucose feeding on the production of exopolysaccharides by Tremella fuciformis spores. Appl. Biochem. Biotechnol., 152(3), 366-371.

\title{
EGZOPOLISACHARYDY DROŻDŻOWE: WGLAD W OPTYMALNE WARUNKI BIOSYNTEZY, SKŁAD CHEMICZNY I WŁAŚCIWOŚCI FUNKCJONALNE - ARTYKUŁ PRZEGLĄDOWY
}

\begin{abstract}
STRESZCZENIE
Egzopolisacharydy drożdżowe (EPS) nie są dobrze poznaną grupą metabolitów. Niektóre wykazują działanie immunostymulujące i przeciwnowotworowe oraz antyoksydacyjne. Inne wiążą metale ciężkie i mogą być bioaktywnymi składnikami żywności. Potencjał EPS ujawnia się także w ich wykorzystaniu jako substancji zagęszczających i stabilizujących. Przemysłowe otrzymywanie EPS jest ograniczone głównie małą wydajnością ich biosyntezy. Optymalne warunki ich biosyntezy wymagają dużego natlenienia i niskiej temperatury, co zależy od fizjologii szczepu producenckiego. Podłoże powinno zawierać sacharozę jako źródło węgla oraz siarczan amonu jako nieorganiczne źródło azotu, a stosunek C:N powinien wynosić 15:1. Hodowle są długotrwałe, a największa akumulacja polimerów jest obserwowana po czwartej bądź piątej dobie. Struktura drożdżowych EPS jest złożona i zależy od szczepu i warunków hodowli. Strukturę EPS drożdżowych mogą stanowić liniowe mannany, pullulan, glukooligosacharydy, galaktooligosacharydy i inne heteropolisacharydy zawierające wiązania: $\alpha-1,2 ; \alpha-1,3 ; \alpha-1,6 ; \beta-1,3 ; \beta-1,4$. Mannoza i glukoza mają największy udział w składzie egzopolisacharydów drożdżowych.
\end{abstract}

Słowa kluczowe: drożdże, egzopolisacharydy, EPS

For citation - Do cytowania

Gientka, I., Błażejak, S., Stasiak-Różańska, L., Chlebowska-Śmigiel, A. (2015). Exopolysaccharides from yeast: insight into optimal conditions for biosynthesis, chemical composition and functional properties - review. Acta Sci. Pol. Technol. Aliment., 14(4), 283-292. DOI: 10.17306/J.AFS.2015.4.29 